\title{
THE INFLUENCE OF INITIAL IRRIGATION ON THE GROWTH OF TWO HYBRIDS OF EUCALYPTUS
}

\author{
Carla Deisiane de Oliveira Costa ${ }^{1 *}$, Adriano da Silva Lopes ${ }^{1}$, Kelvin Rosalvo Melgar Brito ${ }^{1}$, Vinicius Dionisio \\ de Andrade ${ }^{1}$, Carlos Diogo Batista Viana ${ }^{1}$, Thiago Augusto Gomes Xavier ${ }^{1}$ \\ ${ }^{1}$ Universidade Estadual de Mato Grosso do Sul, Aquidauana, Mato Grosso do Sul - carladeisiane@uems.br*; lopes@uems.br; \\ kelvin_rosalvo@hotmail.com; vdandrade11@gmail.com; diogo_viana94@hotmail.com; thiagofl_xavier@hotmail.com
}

Received for publication: 09/02/2018 - Accepted for publication: 29/05/2018

\begin{abstract}
In order to maximize the productivity of forest species, techniques such as irrigation have been used. The objective of this study was to evaluate the water use efficiency and the influence of the irrigation located in the growth of the hybrids of eucalyptus Grancam and Urograndis at 65 months. The study was carried out in the experimental area of the State University of Mato Grosso do Sul (UEMS), in Aquidauana (state of Mato Grosso do Sul, Brazil). The experimental design was randomized blocks with subdivided plots. The treatments used in the plots were two irrigation systems (microsprinkler and drip) and one control treatment with no irrigation (dryland), and in the subplots, the two hybrids of eucalyptus: Grancam (Eucalyptus grandis x Eucalyptus camaldulensis) and Urograndis (Eucalyptus urophylla $\mathrm{x}$ Eucalyptus grandis), submitted to irrigation up to the $53^{\circ}$ month after planting (MAP). The results were submitted to the analysis of variance and the Tukey test for means comparisons at $5 \%$ of probability. The use of irrigation in eucalyptus influences the productivity, providing increased wood volume, height of plants and diameter at breast height (DBH). The hybrid Grancam showed greater increase in height, and Urograndis increased in DBH. The higher efficiency of water use for the volumetric production of wood was observed in drip irrigation for the hybrid Grancam. The hybrid Urograndis is more efficient in the use of water for the volumetric production of wood regardless of the treatment.

Keywords: Eucalyptus irrigated, volumetric production of wood, efficiency in water use.
\end{abstract}

\section{Resumo}

Influência da irrigação inicial no crescimento de dois híbridos de eucalipto. Com o intuito de maximizar a produtividade de espécies florestais, técnicas como a irrigação podem ser utilizadas. Este trabalho teve como objetivo avaliar a eficiência do uso da água e a influência da irrigação localizada no crescimento dos híbridos de eucalipto Grancam e Urograndis aos 65 meses. O trabalho foi realizado na área experimental da Universidade Estadual de Mato Grosso do Sul (UEMS), em Aquidauana (MS). O delineamento experimental utilizado foi o de blocos casualizados, com parcelas subdivididas. Os tratamentos empregados nas parcelas foram dois sistemas de irrigação (microaspersão e gotejamento) e um tratamento controle sem irrigação (sem irrigação), e, nas subparcelas, dois híbridos de eucalipto: Grancam (Eucalyptus grandis x Eucalyptus camaldulensis) e Urograndis (Eucalyptus urophylla x Eucalyptus grandis), submetidos à irrigação até o $53^{\circ}$ mês após o plantio (MAP). Os resultados foram submetidos à análise de variância e ao teste Tukey para comparações de médias a $5 \%$ de probabilidade. A utilização da irrigação no eucalipto influencia na produtividade, proporcionando aumento de volume de madeira, altura das plantas e diâmetro à altura do peito (DAP). O híbrido Grancam apresentou maior incremento em altura, e o Urograndis maior incremento em DAP. A maior eficiência do uso da água para a produção volumétrica de madeira foi observada na irrigação por gotejamento para o híbrido Grancam. O híbrido Urograndis é mais eficiente no uso da água para a produção volumétrica de madeira, independentemente do tratamento.

Palavras-chave: Eucalipto irrigado, produção volumétrica de madeira, eficiência no uso da água.

\section{INTRODUCTION}

Brazil is the second country with the highest amount of planted forests in the world, which takes up about 7,840,000 hectares. Among the plantations carried out in this area, about 5.7 million hectares (72.2\%) are planted with Eucalyptus (IBÁ, 2017). According to the Brazilian Association of Planted Forest Producers (ABRAF, 2013), eucalyptus is the most used forest essence in reforestation programs in Brazil due to its rapid growth characteristics and good adaptation to the edaphoclimatic conditions existing in the country. In addition, according to Miranda et al. (2015), the multiple uses of its wood is one of the causes of the preference for commercial plantations.

The cultivation of Eucalyptus is spread over almost the entire national territory. Much of the cultivated area presents limitations regarding plant growth due to the low soil fertility and for being subjected to long periods

FLORESTA, Curitiba, PR, v. 49, n. 1, p. 125-132, jan/mar 2019.

Costa. C. D. O et.al.

ISSN eletrônico 1982-4688

DOI: $10.5380 /$ rf.v49 i1.57825 
of hydric deficit (VELLINI et al., 2008). In order for a eucalyptus forest to have significant productions, one of the techniques the producer can use is irrigation, which aims to provide controlled water supply to the forest species, in sufficient quantity and at the right time, complementing natural precipitation (FERNANDES et al., 2012). So, one of the alternatives is the use of located irrigation, which, in addition to being more efficient, provides the proper amount of water without waste. This occurs because the water is applied to the soil directly in the root system of the plants, in small quantities and high frequency. Water is of utmost importance for the growth of plants.

Works have been developed in order to maximize the productivity of forest species with the use of irrigation. It is known that this technique is widely used and its influence on forests has been taken into account in large enterprises lately (ALENCAR et al., 2009).

According to Stape et al. (2010), eucalyptus plants are very demanding on water throughout the cycle, especially in the establishment stage. Lima et al. (2008) state that the availability of water affects plant growth because it controls the opening of the stomas, the photosynthetic activity and, consequently, the production of biomass. The decrease in the amount of water in the soil reduce the water potential in leaf and stomatal conductance, promoting the closure of the stomata, affecting the accumulation of photo-assimilated and reducing the wood production .

Similar results were observed by Fernandes et al. (2012) and Vellini et al. (2008), which verified higher values of plant height and stem diameter for the irrigated treatments, and Reis et al. (2006), which reported having found higher values of wood volume. In addition, Oliveira et al. (2013), studying the application of water by different irrigation systems, showed that the water content in the soil provided higher plant height and wood volume in the initial stages of eucalyptus growth when compared to the dry farming.

The knowledge of the efficiency of water use is necessary for the selection of species. Some species of the genre Eucalyptus present water saving mechanisms. Thus, knowledge of the efficiency of water use by plants is of great importance, since plants that use it more efficiently are more productive (LIMA el al., 2008). Based on the above considerations, it is verified the importance of irrigation on the growth of eucalyptus. Therefore, the objective of this work was to evaluate the efficiency of water use and the influence of irrigation on the growth of hybrids of Grancam and Urograndis eucalyptus at 65 months.

\section{MATERIAL AND METHODS}

The study was carried out in the experimental area of the State University of Mato Grosso do Sul (UEMS), in the municipality of Aquidauana (state of Mato Grosso do Sul, Brazil), at the geographic coordinates $20^{\circ} 27^{\prime} 08^{\prime \prime} \mathrm{S}$ and $55^{\circ} 40^{\prime} 15^{\prime \prime} \mathrm{W}$, with average altitude of 191 meters. The climate of the region, according to the classification of Köopen, is Aw, defined as warm tropical sub-humid, with rainy season in summer and dry in winter, and average annual precipitation of 1,200 $\mathrm{mm}$. According to Schiavo et al. (2010), the soil is classified as Red Dystrophic Argisoil.

The data of the meteorological elements were obtained through the meteorological station of UEMS, installed in the University Unit of Aquidauana, and consisted of daily data of temperature, relative humidity of the air, global solar radiation and wind speed, for the period of conduction of the experiment.

The experimental delineation used was of random block design with subdivided plots. The treatments employed in the plots were two irrigation systems (micro-sprinkler and drip irrigation) and a control treatment without irrigation, and, in subplots, two hybrids of eucalyptus: Grancam, clone 1277 (Eucalyptus grandis x Eucalyptus camaldulensis) and Urograndis, clone I224 (Eucalyptus urophylla x Eucalyptus grandis).

The planting of eucalyptus hybrids was conducted in April 2011, with 2.25 x $4.00 \mathrm{~m}$ spacing. Their fertilization was conducted in accordance with the recommendations of Andrade (2004), from the chemical analysis of the soil. The hybrids had been irrigated until $53^{\circ}$ month after the plantation (MAP) (September of 2015).

Auto compensating drippers were used with outflow of $2.4 \mathrm{~L} \mathrm{~h}^{-1}$ and $0.5 \mathrm{~m}$ of spacing between the senders, pressure of service of $10 \mathrm{~m} \mathrm{c.a.,}$, and micro sprinklers with unitary outflow of $48 \mathrm{~L} \mathrm{~h}^{-1}$, ray of reach of $1.5 \mathrm{~m}$ and pressure of service of $40 \mathrm{~m}$ c.a., which were installed in one sprinkler per plant at $0.3 \mathrm{~m}$ of each plant. The handling of the irrigation was based on the estimate of the evapotranspiration of reference from the Equation of PenmanMonteith (ALLEN et al., 1998). The evapotranspiration of the culture was estimated with adaptations for located irrigation (Equations 1 and 2) (BERNARDO et al., 2006). 
(1)

$$
\text { ETc }=\text { ETo } k_{c}
$$

Where: $\mathrm{ET}_{\mathrm{c}}$ : evapotranspiration of culture; ETo: evapotranspiration of reference; $\mathrm{K}_{\mathrm{c}}$ : crop coefficient (0.82) for the eucalyptus according to Alves et al.(2013).

$$
E T c_{\text {Loc }}=E T c k_{L}
$$

Where: $\mathrm{K}_{\mathrm{L}}$ : factor of correction according to the method of located irrigation, estimated in accordance with Equation 3, according to Keller and Bliesner (1990).

$$
\mathrm{k}_{\mathrm{L}}=0,1 \sqrt{\mathrm{PAM}}
$$

Where: PAM: percentage of wet area calculated according to Bernardo et al. (2006).

Drip and micro-sprinkler irrigation systems resulted in PAM values of 25 and 75\%, respectively. For the calculation of the irrigation plate, the easily available water for located irrigation was used as criterion (Equation 4).

$$
A F D_{L o c}=\left(\theta_{c c}-\theta_{p m p}\right) Z p \frac{P A M}{100}
$$

Where: $A_{\text {Loc }}$ : easily available water for located irrigation; $\theta_{c c}$ : humidity of the soil in the field capacity - matric potential of $-10 \mathrm{kPa} \mathrm{m} / \mathrm{m}^{3} ; \theta_{p m p}$ : humidity of the soil in the point of permanent withering - matric potential of $-1500 \mathrm{kPa} \mathrm{m} 3 / \mathrm{m} 3$; Z: depth of the radicular system, using the value of $970 \mathrm{~mm}$, according to Reis et al. (2006); p: factor of water depletion in the ground for coniferous wood (0,7), according to Allen et al. (1998).

$\mathrm{AFD}_{\mathrm{Loc}}$ was 31.1 and $93.3 \mathrm{~mm}$ for the micro-sprinkler and drip equipment, respectively. However, due to the high frequency and low intensity of water application, characteristic of irrigation, irrigation was made where the sum of ETc $c_{\text {Loc }}$ was greater than or equal to $9 \mathrm{~mm}$.

The evaluations were carried out at 5 years of eucalyptus growth, of the $54^{\text {th }}$ MAP (October 2015) to $65^{\text {th }}$ MAP (September of 2016). This period corresponds to the following months after the irrigation were ceased. Plant height and diameter at breast height (DBH) were measured, and stem volume was also estimated (Equation 5).

$$
V C=A_{D A P} A L T 0,5 D P
$$

In which: VC: stem volume $\left(\mathrm{m}^{3} \mathrm{ha}^{-1}\right)$; $\mathrm{A}_{\mathrm{DAP}}$ : stem area at breast height $\left(\mathrm{m}^{2}\right)$; ALT: plant height $(\mathrm{m})$; 0.5: Eucalyptus form factor, according to Villas Bôas et al. (2009); DP: population density (plants ha ${ }^{-1}$ ).

The efficiency of water use for the volumetric production of wood in each irrigation system (microsprinkler and drip) and without irrigation was obtained using equation 6.

$$
E U A_{V M}=\frac{V M}{L T}
$$

Where: EUAvm: water use efficiency for wood production $\left(\mathrm{m}^{3} \mathrm{ha}^{-1} \mathrm{~m}^{3}\right)$, VM: wood volume $\left(\mathrm{m}^{3} \mathrm{ha}^{-1}\right)$; LT: total quantity of water (irrigation + precipitation) $\left(\mathrm{m}^{3}\right)$.

The results were submitted to analysis of variance and the Tukey test for comparisons of averages at $5 \%$ probability, being used a software SISVAR.

\section{RESULTS}

In the period in which the experiment was conducted, there was a total of $1,420 \mathrm{~mm}$ of precipitation, i.e. above the annual average $(1,200 \mathrm{~mm})$, being the month of January $\left(57^{\circ} \mathrm{MAP}\right)$ the wettest and the months of June and July $\left(62^{\circ}\right.$ to $\left.63^{\circ} \mathrm{MAP}\right)$ the ones with the lowest rainfall indexes (Figure 1). It is observed, too, that the maximum temperature occurred in October 2015 (54 $\left.{ }^{\circ} \mathrm{MAP}\right)$ and the minimum temperature in the months of June and July of $2016\left(62^{\circ}\right.$ to $\left.63^{\circ} \mathrm{MAP}\right)$. 


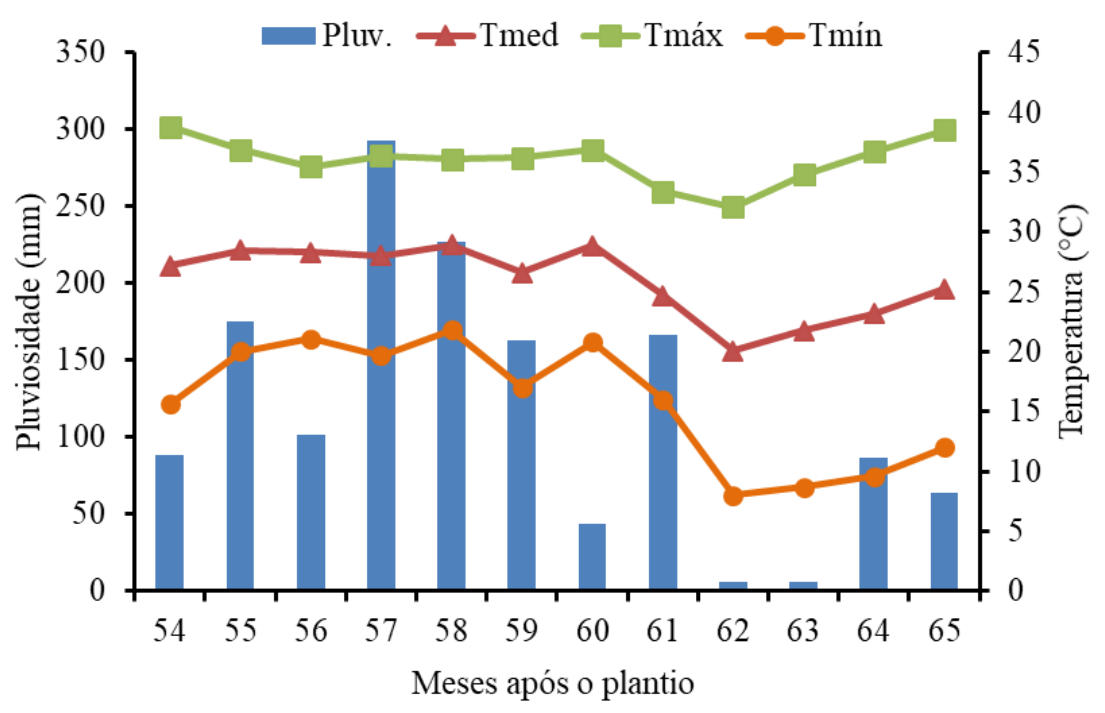

Figure 1. Precipitation and temperature (average, maximum and minimum) of the municipality of Aquidauana (state of Mato Grosso do Sul, Brazil) between October 2015 (54 ${ }^{\circ}$ MAP) and September 2016 $\left(65^{\circ} \mathrm{MAP}\right)$.

Figura 1. Precipitação e temperatura (média, máxima e mínima) do município de Aquidauana (MS) entre outubro

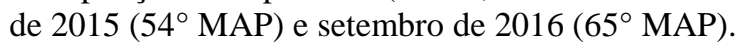

The total leaflet (LT) of the implantation period up to the $65^{\circ} \mathrm{MAP}$ for the micro-sprinkler system was 6.6 and $20.7 \%$ higher than that of the drip systems and without irrigation, respectively (Table 1).Related to drip, it provided a LT $13.2 \%$ bigger than the non-irrigated area.

Table 1. Applied irrigation water depth up to the $53^{\circ} \mathrm{MAP}$ and total irrigation water depth of the period of implantation up to the $65^{\circ} \mathrm{MAP}$.

Tabela 1. Lâmina de irrigação aplicada até o $53^{\circ}$ MAP e lâmina total do período de implantação até o $65^{\circ}$ MAP.

\begin{tabular}{lccc}
\hline & LI & Precipitation & LT \\
\hline Micro sprinkler & 1527.92 & 7376.45 & 8904.37 \\
Drip system & 973.57 & 7376.45 & 8350.02 \\
No irrigation & - & 7376.45 & 7376.45 \\
\hline
\end{tabular}

LI: irrigation plate; LT: total plate.

Irrigation provided better dendrometric characteristics in relation to treatment without irrigation. The hybrids showed different behaviors for each individual feature evaluated, being an important factor for irrigation productivity of two hybrids (Table 2).

Table 2. Comparison of averages between the irrigated hybrids for diameter at breast height (DBH), plant height and wood volume.

Tabela 2. Comparação de médias entre os híbridos irrigados para diâmetro à altura do peito (DAP), altura de plantas e volume de madeira. 


\begin{tabular}{|c|c|c|c|c|}
\hline \multirow[b]{2}{*}{ Treatments } & \multicolumn{4}{|c|}{ Months after planting (MAP) } \\
\hline & $53 *$ & 54 & 59 & 65 \\
\hline & \multicolumn{4}{|c|}{ DAP $(\mathbf{c m})$} \\
\hline Micro sprinkler & $15.60 \mathrm{~A}$ & $16.89 \mathrm{~A}$ & $17.19 \mathrm{~A}$ & $18.14 \mathrm{~A}$ \\
\hline Drip system & $15.26 \mathrm{~A}$ & $16.53 \mathrm{~A}$ & $16.85 \mathrm{AB}$ & $17.50 \quad \mathrm{~B}$ \\
\hline No irrigation & $15.08 \mathrm{~A}$ & $15.40 \quad \mathrm{~B}$ & $16.16 \quad \mathrm{~B}$ & $16.77 \quad \mathrm{C}$ \\
\hline DMS & 1.15 & 0.99 & 0.73 & 0.72 \\
\hline $\mathrm{CV}(\%)$ & 4.83 & 3.97 & 2.86 & 1.95 \\
\hline Hybrids & ------------------------ & ------------------------ & ----------------------- & ----------------------- \\
\hline Grancam & $14.78 \mathrm{~b}$ & $16.29 \mathrm{a}$ & $16.49 \mathrm{a}$ & $16.94 \mathrm{~b}$ \\
\hline Urograndis & $16.18 \mathrm{a}$ & $17.14 \mathrm{a}$ & $17.56 \mathrm{a}$ & $18.55 \mathrm{a}$ \\
\hline DMS & 0.69 & 1.19 & 1.18 & 0.89 \\
\hline \multirow[t]{2}{*}{ CV (\%) } & 4.82 & 5.61 & 5.87 & 4.25 \\
\hline & \multicolumn{4}{|c|}{ Height (m) } \\
\hline \multicolumn{5}{|l|}{ Treatments } \\
\hline Micro sprinkler & $20.00 \mathrm{AB}$ & $20.06 \mathrm{AB}$ & $22.33 \mathrm{~A}$ & $22.63 \mathrm{~A}$ \\
\hline Drip system & $20.65 \mathrm{~A}$ & $20.67 \mathrm{~A}$ & $22.59 \mathrm{~A}$ & $23.69 \mathrm{~A}$ \\
\hline No irrigation & $18.00 \quad \mathrm{~B}$ & $18.02 \mathrm{~B}$ & $19.81 \mathrm{~B}$ & $19.85 \quad \mathrm{~B}$ \\
\hline DMS & 2.14 & 2.08 & 1.37 & 1.95 \\
\hline CV (\%) & 6.97 & 6.93 & 4.12 & 5.78 \\
\hline Hybrids & ---------------------- & |---------------------- & $\begin{array}{l}\text {--------------------- } \\
\end{array}$ & ----------------------- \\
\hline Grancam & $21.21 \mathrm{a}$ & $21.65 \mathrm{a}$ & $24.13 \mathrm{a}$ & $24.70 \mathrm{a}$ \\
\hline Urograndis & $18.85 \mathrm{~b}$ & $19.09 \mathrm{~b}$ & $20.08 \mathrm{~b}$ & $21.63 \mathrm{~b}$ \\
\hline DMS & 0.77 & 1.92 & 1.79 & 1.90 \\
\hline \multirow[t]{2}{*}{ CV (\%) } & 4.15 & 5.93 & 6.57 & 5.58 \\
\hline & \multicolumn{4}{|c|}{ Wooden volume $\left(\mathrm{m}^{3} \mathrm{ha}^{-1}\right)$} \\
\hline \multicolumn{5}{|l|}{ Treatments } \\
\hline Micro sprinkler & $212.27 \mathrm{~A}$ & $250.74 \mathrm{~A}$ & $288.41 \mathrm{~A}$ & $325.21 \mathrm{~A}$ \\
\hline Drip system & $202.29 \mathrm{~A}$ & $247.67 \mathrm{~A}$ & $279.78 \mathrm{AB}$ & $310.67 \mathrm{~A}$ \\
\hline No irrigation & $182.78 \mathrm{~A}$ & $186.34 \mathrm{~B}$ & $227.91 \quad \mathrm{~B}$ & $244.19 \quad \mathrm{~B}$ \\
\hline DMS & 35.19 & 52.90 & 52.93 & 47.47 \\
\hline CV (\%) & 11.34 & 15.11 & 13.01 & 10.55 \\
\hline Hybrids & ------------------------ & ------------------------ & ------------------------ & ------------------------ \\
\hline Grancam & $211.26 \mathrm{a}$ & $252.15 \mathrm{a}$ & $287.55 \mathrm{a}$ & $310.42 \mathrm{a}$ \\
\hline Urograndis & $193.64 \mathrm{a}$ & $246.27 \mathrm{a}$ & $280.65 \mathrm{a}$ & $325.47 \mathrm{a}$ \\
\hline DMS & 24.08 & 48.81 & 47.78 & 45.68 \\
\hline CV (\%) & 12.88 & 12.78 & 10.20 & 9.97 \\
\hline
\end{tabular}

For the Grancam hybrid, it was observed bigger efficiency of the water use for the irrigation in relation to the ones without irrigation (Table 3).

Table 3. Estimation of the water use efficiency for the volumetric production of wood at the $65^{\circ}$ MAP of the eucalyptus hybrids Grancam and Urograndis for irrigation systems.

Tabela 3. Estimativa da eficiência do uso da água para a produção volumétrica de madeira, ao $65^{\circ}$ MAP, dos híbridos de eucalipto Grancam e Urograndis para os sistemas de irrigação.

\begin{tabular}{|c|c|c|c|c|}
\hline \multicolumn{2}{|l|}{ Treatments } & \multirow{2}{*}{$\begin{array}{c}\begin{array}{c}\text { VM } \\
\mathbf{m}^{\mathbf{3}} \mathbf{h a}^{-1}\end{array} \\
311.28\end{array}$} & \multirow{2}{*}{$\begin{array}{c}\begin{array}{c}\mathbf{L T} \\
\mathbf{m}^{\mathbf{3}}\end{array} \\
8.90\end{array}$} & \multirow{2}{*}{$\begin{array}{c}\begin{array}{c}\text { EUAvm } \\
\mathbf{m}^{\mathbf{3}} \mathbf{h a}^{-\mathbf{1}} \mathbf{~ m}^{\mathbf{3}}\end{array} \\
35\end{array}$} \\
\hline Grancam & Micro sprinkler & & & \\
\hline & Drip system & 309.56 & 8.35 & 37 \\
\hline & No irrigation & 215.75 & 7.38 & 29 \\
\hline \multirow[t]{3}{*}{ Urograndis } & Micro sprinkler & 339.14 & 8.90 & 38 \\
\hline & Drip system & 311.79 & 8.35 & 37 \\
\hline & No irrigation & 272.63 & 7.38 & 37 \\
\hline
\end{tabular}

VM: wooden volume; LT: total blade; U.S.A.vM: efficiency of the use of the water for wooden production.Grancam Eucalyptus grandis $\mathrm{x}$ E. camaldulensis, Urograndis: e.urophylla x E. grandis.

FLORESTA, Curitiba, PR, v. 49, n. 1, p. 125-132, jan/mar 2019.

Costa. C. D. O et.al.

ISSN eletrônico 1982-4688

DOI: $10.5380 /$ rf.v49 i1.57825 


\section{DISCUSSION}

It is observed that the water availability made possible greater increment in the DAP. Bigger values had been observed for the treatments irrigated in $54^{\circ}$ and $65^{\circ} \mathrm{MAP}$, being verified for this last month the biggest value for micro-sprinkler. There was an increment in irrigated planting DAP of 14 and $19.3 \%$ for micro sprinkler and drip, respectively, at $65^{\circ}$ MAP. According to Sette Junior et al. (2013), the disponibility of water stimulates the increase of foreign exchange activity rate, resulting in greater diameter.

There was greater heights of plants for the irrigated treatments to $59^{\circ}$ and $65^{\circ} \mathrm{MAP}$. Thus, it can be affirmed that irrigation provided greater growth of eucalyptus, avoiding possible metabolic disturbances caused by water deficit. Jung et al. (2017) also noted that irrigation was essential so that the height of eucalyptus in the early stages have significantly bigger growth than non-irrigated eucalyptus. There was an increase in height to the irrigated treatments of 8.2 and $4.6 \%$ for drip and micro-sprinkler, respectively, to $65^{\circ} \mathrm{MAP}$, in relation to treatment without irrigation. Fernandes et al. (2012), evaluating the growth of eucalyptus at 5 years, observed higher values of DBH and height to the irrigated treatments, stating that the availability of water affects the growth of eucalyptus. Vellini et al. (2008) also observed greater increments in height and stem diameter in irrigated eucalyptus clones.

According to Fernandes et al. (2014), some clones of eucalyptus under irrigation conditions present higher rates of photosynthesis, stomatal conductance and transpiration, which can result in increased timber production in these species, as well as observed in this work. In this way, the forest productivity is influenced directly by the availability of water, as all the vital processes of the plant are affected by water deficit. With respect to hybrids, higher values of $\mathrm{DBH}$ to Urograndis to $65^{\circ} \mathrm{MAP}$, which may be related to the characteristics of the species. According to Baker (2017), this is due to the characteristic of silvicultural growth of $e$. grandis, and, due to the quality of wood E.urophylla.

Villas Bôas et al. (2009), evaluating the growth of different species, also observed higher values of DAP to Eucalyptus urophylla. The authors observed average DAP equal to $15.78 \mathrm{~cm}$ in eucalyptus plantation to 8 years without irrigation for this species, highlighting the importance of irrigation since the hybrids irrigated are superior to this value to 5 years. The Grancam hybrid showed higher height values in relation to Urograndis. This may be related to a better interaction of genotype with the environment, enabling greater height of this hybrid. Oliveira $e t$ al. (2013), evaluating the same hybrids, also observed greater height values for the Grancam hybrid. The authors claim that this parameter is strongly linked to genetic character.

With respect to the volume of wood, irrigation provided higher values at 54 and 65 MAP. The increase in the volume of wood per hectare was influenced by the increase of the DAP and height variables, being the DAP the main variable influencing the productivity gain. Irrigation provided a volume of wood from $325.21 \mathrm{~m}^{3} \mathrm{ha}^{-1}$ for the micro-sprinkler and $310.67 \mathrm{~m}^{3} \mathrm{ha}^{-1}$ for the drip, there being a volumetric increase of 33.2 and $27,2 \%$, respectively, to the $65 \mathrm{MAP}$, in relation to the treatment without irrigation, with a volume of wood equal to 244,19 $\mathrm{m}^{3} \mathrm{ha}^{-1}$.

Reis et al. (2006), evaluating the growth of hybrids of eucalyptus, also observed more wood for the irrigated treatments. The authors complement that the use of irrigation in eucalyptus forests provides an increase in the volume of wood in shorter time, even in years of high rainfall index. This difference can be larger in years of prolonged drought.

Among the hybrids, there was no difference in the wood volume. This may be related to the highest value of DAP provided by hybrid Urograndis and greater height by Grancam hybrid, compensating for the volume calculation, which takes into account these variables. Reis el al. (2006) noted that the hybrid Grancam tendency for greater height, DBH, and volume in conditions without irrigation, being the hybrid Urogrand the most responsive to irrigation. In this work, it was observed only for the DAP. With regards to height, there was better response of irrigation for hybrid Grancam. For volume, hybrids exhibited similar behaviors.

It turns out that irrigation provided best dendrometric features and that there were different behaviors among the hybrids. Similar results were obtained by Vellini et al. (2008), who observed that the reduction in water availability affected negatively the growth of hybrids, and considerable variability between clones of eucalyptus as growth characteristics.

For the Grancam hybrid, it was observed bigger efficiency of the water use for the irrigation. White et al. (2016) observed that plants of Eucalyptus globulus and Eucalyptus nitens irrigated also needed less water to produce $1 \mathrm{~m}^{3}$ of wood. This is of great importance because it demonstrates that irrigating forests increases the efficiency in the use of water resources and maximize wood production. The greater efficiency of water use for volume production of timber was obtained using drip irrigation, in relation to the equipment and without irrigation to the hybrid Grancam. Drip irrigated eucalyptus plants produced $37 \mathrm{~m}^{3} \mathrm{ha}^{-1}$ wood using $1 \mathrm{~m}^{3}$ of water to the Grancam hybrid, while in the micro-sprinkler irrigation, $35 \mathrm{~m}^{3} \mathrm{ha}^{-1}$ and, in the treatment without irrigation, $29 \mathrm{~m}^{3}$ $\mathrm{ha}^{-1}$.

FLORESTA, Curitiba, PR, v. 49, n. 1, p. 125-132, jan/mar 2019. 
With respect to hybrid Urograndis, we observed increased efficiency for micro-sprinkler, showing close values of water use efficiency in three treatments. Stape et al. (2008) observed, in the hybrid planting Urograndis, that irrigation provided greater efficiency in wood production per unit of water consumed. The plants irrigated by micro-sprinkler produced $38 \mathrm{~m}^{3} \mathrm{ha}^{-1}$ of wooden using $1 \mathrm{~m}^{3}$, while in drip irrigation and treatment without irrigation, plants produced $37 \mathrm{~m}^{3} \mathrm{ha}^{-1}$ using the same amount of water. From this form, it is observed that Urograndis is more efficient in the use of water regardless of the treatment, since it uses less water to produce $1 \mathrm{~m}^{3}$ of wood. This behavior occurs due to the rusticity of E. urophylla and resistance to deficit hydric of $e$. grandis. According to Silva et al. (2004), this species prevents drought as its stomas close before any visible wilting occurs.

The Urograndis hybrid, in addition to better quality of wood, presents higher yields in volume and biomass and adaptability to several locations (FERREIRA et al., 2017). For Silva et al. (2004), the adaptation of species to the effects of climate can help in the management of water under different humidity conditions, which is why water use reflects the complexity of factors involved in plant/environment interaction. In addition to the environment, morphological characteristics of the plant influence directly on the efficient use of water. Silva et al. (2004) point out that some species of the genre Eucalyptus feature water-saving mechanisms, such as the presence of thickened, leathery leaf tissue vertical alignment of the leaves, fast closing of stomas, low rates of transpiration and high root/shoot ratio.

\section{CONCLUSIONS}

- The use of irrigation in eucalyptus influences directly in its productivity, providing increased wood volume, height and DBH and showing an increase of productivity equal to 81.02 and $66.48 \mathrm{~m}^{3} \mathrm{ha}^{-1}$ to micro-sprinkler and drip system, respectively, at $65^{\circ} \mathrm{MAP}$.

- The hybrid Grancam showed the highest increase in height, and the largest increase in DAP, at $65^{\circ} \mathrm{MAP}$

- The greater efficiency of water use for the volumetric production of wood was observed in drip irrigation for the hybrid Grancam.

- The hybrid Urograndis is more efficient in the use of water for volumetric production of wood, regardless of treatment.

\section{REFERÊNCIAS}

ALENCAR, C.A.B.; CUNHA, F.F.; MARTINS, C.E.; CÓSER, A.C.; ROCHA, W.S.D.; ARAÚJO, R.A.S. Irrigação de pastagem: Atualidade e recomendações para uso e manejo. Revista Brasileira de Zootecnia, Viçosa, v. 38, p. $98-108,2009$.

ALLEN, R. G.; PEREIRA, L. S.; RAES, D.; SMITH, M. Crop evapotranspiration: guidelines for computing crop requirements. Roma: FAO, 1998, 301 p.

ALVES, M. E. B.; MANTOVANI, E. C.; SEDIYAMA, G. C.; NEVES, J. C. L. Estimate of the crop coefficient for Eucalyptus cultivated under irrigation during initial growth. Cerne, Lavras, v. 19, p. 247 - 253, 2013.

ANDRADE, L. R. M. Corretivos e fertilizantes para culturas perenes e semiperenes. In: SOUSA, D. M. G.; LOBATO, E. Cerrado, correção do solo e adubação. Brasília: Embrapa, 2 ed., 2004, 416 p.

ASSOCIAÇÃO BRASILEIRA DE PRODUTORES DE FLORESTAS PLANTADAS - ABRAF. Anuário estatístico da ABRAF 2013: ano base 2012. Brasília: ABRAF, 2013, 130 p.

BELCHIOR, I. B. Parâmetros dendrométricos de híbridos de eucalipto irrigado. Dissertação (Mestrado em Produção Vegetal), Universidade Estadual de Mato Grosso do Sul, 33p., 2017.

BERNARDO, S.; SOARES, A. A.; MANTOVANI, E. C. Manual de irrigação. $8^{\text {a }}$ ed. Viçosa: UFV, 2006,625 p.

FERNANDES, A.L.T.; FLORÊNCIO, T.M.; FARIA, M.F. Análise biométrica de florestas irrigadas de eucalipto nos cinco anos iniciais de desenvolvimento. Revista Brasileira de Engenharia Agrícola e Ambiental, Campina Grande, v. 16, n. 5, p. 505 - 513, 2012.

FERNANDES, E. T.; CAIRO, P. A. R.; NOVAES, A. B. Respostas fisiológicas de clones de eucalipto cultivados em casa de vegetação sob deficiência hídrica. Ciência Rural, Santa Maria, online, 2014.

FLORESTA, Curitiba, PR, v. 49, n. 1, p. 125-132, jan/mar 2019.

Costa. C. D. O et.al.

ISSN eletrônico 1982-4688

DOI: $10.5380 /$ rf.v49 i1.57825 
FERREIRA, D. H. A. A.; LELES, P. S. S.; OLIVEIRA NETO, S. N.; PAULA, T. R.; COUTINHO, R. P.; SILVA, R. L. Crescimento e produção de eucalipto na região do médio Paraíba do Sul, RJ. Floresta e Ambiente, Rio de Janeiro, v. 24, p. 1 - 9, 2017.

IBÁ - INDÚSTRIA BRASILEIRA DE ÁRVORES. Anuário estatístico da indústria Brasileira de árvores: ano base 2016. Brasília: IBÁ, 2017, 77 p.

JUNG, L.H.; LOPES, A.S.; OLIVEIRA, G.Q.; OLIVEIRA, J.C.L.; FANAYA JÚNIOR, E.D.; BRITO, K.R.M. Irrigação no desenvolvimento inicial de Eucalyptus urophylla $x$ Eucalyptus grandis e Eucalyptus grandis $x$ Eucalyptus camaldulensis. Ciência Florestal, Santa Maria, v. 27, n. 2, p. 655 - 667, 2017.

KELLER, J.; BLIESNER, R. D. Sprinkle and trickle irrigation. New York: Van Nostrand Reinold, 1990,652 p.

LIMA, B. M.; FAZZA, A. C.; SESTARI, I. Eucalipto. In: CASTRO, P. R. C.; KLUGE, R. A.; SESTARI, I. Manual de Fisiologia Vegetal: Fisiologia de cultivos. Piracicaba: Editora Ceres, 2008, 864 p.

MIRANDA, D. L. C.; JUNIOR, V. B.; GOUVEIA, D. M. Fator de forma e equações de volume para estimativa volumétrica de árvores em plantio de Eucalyptus urograndis. Scientia Plena, Aracaju, v. 11, n. 3, p. 1 - 8, 2015.

OLIVEIRA, G. Q.; LOPES, A. S.; JUNG, L. H.; REGO, N. H.; OLIVEIRA, J. C. L. Initial development of two eucalyptus hybrid submitted to irrigation. Engenharia Agrícola, Jaboticabal, v. 34, n. 6, p. 1099 - $1109,2013$.

REIS, G. G.; REIS, M. G. F.; FORTAN, I. C. I.; MONTE, M. A.; GOMES, A. N.; OLIVEIRA, C. H. R. Crescimento de raízes e da parte aérea de clones de híbridos de Eucalyptus grandis x Eucalyptus urophylla e de Eucalyptus camaldulensis x Eucalyptus spp. submetidos a dois regimes de irrigação no campo. Árvore, Viçosa, v. 30, n. 6, p. $921-931,2006$.

SCHIAVO, J. A.; PEREIRA M. G.; MIRANDA, L. P. M.; DIAS NETO, A. H.; FONTANA, A. Caracterização e classificação de solos desenvolvidos de arenitos da formação Aquidauana-MS. Revista Brasileira de Ciência do Solo, Viçosa, v. 34. p. 881 - 889. 2010.

SETTE, J. R. C. R.; LACLAU, J. P.; TOMAZELLO FILHO, M.; MOREIRA, R. M.; BOUILLET, J. P.; RANGER, J.; ALMEIDA, J. C. R. Source-driven remobilizations of nutrients within stem wood in Eucalyptus grandis plantations. Trees - Structure and Function, Berlin, v. 27, n. 4, p. 827 - 839, 2013.

SILVA, W.; SEDIYAMA, T.; SILVA, A. A.; CARDOSO, A. A. Índice de consumo e eficiência do uso da água em eucalipto, submetido a diferentes teores de água em convivência com braquiária. Revista Floresta, Curitiba, v. 34, n. 3, p. $325-335,2004$.

STAPE, J. L.; BINKLEY, D.; RYAN, M. G. Production and carbon allocation in a clonal Eucalyptus plantation with water and nutrient manipulations. Forest Ecology and Management, Amsterdam, v. 255, p. 920 - 930, 2008.

STAPE, J. L; BINKLEY D.; RYAN, M. G.; FONSECA, R.A.; LOOS, R.A.; TAKAHASHI, E.N.; SILVA, C. R.; SILVA, S. R.; HAKAMADA, R. E.; FERREIRA, J. M. A.; LIMA, M. N.; GAVA, J. L.; LEITE, F. P.; ANDRADE, H. B.; ALVES, J. M.; SILVA, G. G. C.; AZEVEDO, M. R. The Brazil eucalyptus potential productivity project: influence of water, nutrients and stand uniformity on wood production. Forest Ecology and Management, Amsterdam, v. 259, n. 9., p. 1684 - 1694, 2010.

VELlini, A. L. T. T.; PAUlA, N. F.; ALVES, P. L. C. A.; PAVANI, L. C.; BONINE, C. A. V.; SCARPINATI, E. A.; PAULA, R. C. Respostas fisiológicas de diferentes clones de eucalipto sob diferentes regimes de irrigação. Árvore, Viçosa, v. 32, p. 651 - 663, 2008.

VILLAS BÔAS, O.; MAX, J. C. M.; MELO, A. C. G. Crescimento comparativo de espécies de Eucalyptus E Corymbia no município de Marília, SP. Revista Instituto Florestal, São Paulo, v. 21, p. 63 - 72, 2009.

WHITE, D.; BEADLE, C.; WORLEDGE, D.; HONEYSETT, J. Wood production per evapotranspiration was increased by irrigation in plantations of Eucalyptus globulus and E. nitens. New Forests, New York, v. 47, p. 303 - 317, 2016. 